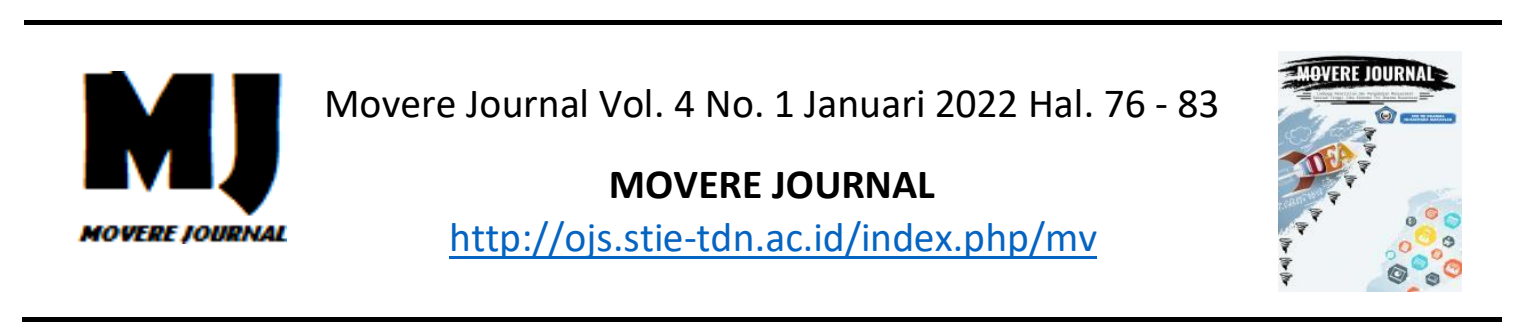

\title{
ANALISIS PENERAPAN PENGEMBANGAN KEMAMPUAN KERJA TERHADAP PRESTASI KERJA DI PT. PELABUHAN INDONESIA IV MAKASSAR (PERSERO)
}

\author{
Nurwahidah Mashuddin \\ Universitas Muslim Maros \\ Email : nurwahidah@umma.ac.id
}

\begin{abstract}
Abstrak: Tujuan dari penelitian ini adalah untuk mengetahui pengaruh kemampuan kerja terhadap prestasi kerja karyawan pada PT Pelabuhan Indonesia IV Makassar (Persero) baik secara parsial maupun simultan. Penelitian ini merupakan penelitian explanatory research dengan menggunakan pendekatan kuantitatif dan teknik pengumpulan data melalui kuesioner dan observasi. Sampel yang digunakan sebanyak 75 responden pada perusahaan. Analisis data yang digunakan adalah analisis deskriptif dan analisis regresi linear berganda. Sedangkan untuk uji hipotesis digunakan Uji-F dan Uji-T. Hasil pengujian hipotesis menunjukkan bahwa; 1)secara simultan kemampuan kerja berpengaruh positif dan signifikan terhadap prestasi kerja PT Pelabuhan Indonesia IV Makassar (Persero). 2) Variabel kemampuan kerja yang berpengaruh dominan pada prestasi kerja di PT Pelabuhan Indonesia IV Makassar (Persero).
\end{abstract}

Kata Kunci: kemampuan kerja ; prestasi kerja

\begin{abstract}
The purpose of this study was to determine the effect of work ability on employee performance at PT Pelabuhan Indonesia IV Makassar (Persero) either partially or simultaneously. This research is an explanatory research using a quantitative approach and data collection techniques through questionnaires and observations. The sample used as many as 75 respondents in the company. The data analysis used is descriptive analysis and multiple linear regression analysis. Meanwhile, to test the hypothesis, the F-Test and T-Test are used. The results of hypothesis testing show that; 1) Simultaneously, work ability has a positive and significant effect on the work performance of PT Pelabuhan Indonesia IV Makassar (Persero). 2) The variable of work ability that has a dominant effect on work performance at PT Pelabuhan Indonesia IV Makassar (Persero).
\end{abstract}

Keywords : work ability; work performance 


\section{A. PENDAHULUAN}

Kemampuan kerja seorang karyawan sangat mempengaruhi prestasinya di perusahaan, yang menjadi bahan pertimbangan seorang atasan atau manajer dalam memberikan penilaian. Kemampuan kerja yang dimaksud adalah di mana pada saat melakukan proses kegiatan kerja, seorang karyawan mampu menunjukkan kualitas sumber daya manusia yang di milikinya dengan memberikan kontribusi yang maksimal terhadap perusahaan tempat ia bekerja.

Menurut Thoha (2011) kemampuan merupakan salah satu unsur dalam kematangan berkaitan dengan pengetahuan atau keterampilan yang dapat diperoleh dari pendidikan, pelatihan dan suatu pengalaman.

Menurut Gibson, dkk. (2009) kemampuan adalah sifat yang dibawah sejak lahir/dipelajari yang memungkinkan seseorang menyelesaikan tugasnya. Kemampuan menunjukkan potensi orang untuk melaksanakan tugas/pekerjaan.

Istilah prestasi kerja sering kita

\section{B. TELAAH LITERATUR DAN PENGEMBANGAN HIPOTESIS}

\section{Kemampuan Kerja}

Organisasi sebagai suatu sistem, keberhasilan pencapaian tujuannya ditentukan oleh bagaimana sub - sub sistem baik internal maupun eksternal saling bersinergi membentuk suatu kekuatan. Salah satu sub sistem oarganisasi yang sangat penting keberadaannya adalah organisasi dapat dikatakan sebagai bagian yang paling essensial, karena maju mundurnya suatu organisasi sangan ditentukan oleh kualitas sumber daya manusianya, sehingga peningkatan kualitas SDM harus dilakukan secara berkelanjutan dan dengar atau sangat penting bagi sebuah perusahaan atau organisasi untuk mencapai tujuannya. Dalam konteks pengembangan sumber daya manusia prestasi kerja seorang karyawan dalam sebuah perusahaan sangat dibutuhkan untuk mencapai prestasi kerja bagi karyawan itu sendiri maupun perkelompok demi keberhasilan perusahaan

Prestasi kerja adalah hasil upaya seseorang yang ditentukan oleh kemampuan karakteristik pribadinya serta persepsi terhadap perannya terhadap pekerjaan Sutrisno (2011:149). Menurut Mangkunegara (2002:33) prestasi kerja adalah hasil kerja secara kualitas dan kuantitas yang dicapai oleh seorang pegawai dalam melaksanakan tugasnya sesuai dengan tanggung jawab yang diberikannya. Prestasi kerja adalah suatu hasil kerja yang dicapai seseorang dengan melaksanakan tugas yang dibebankan kepadanya yang didasarkan atas kecakapan, pengalaman, kesungguhan serta waktu Hasibuan (2008:94).

sistematis. Peningkatan kualitas SDM ini dilakukan untuk meningkatkan kemampuan pegawai dalam menangani berbagai aktivitas organisasi. Disisi lain organisasi terus mengalami perkembangan seiring dengan semakin besarnya organisasi.

Kualitas sumberdaya manusia merupakan kemampuan manusia untuk melakukan sesuatu pekerjaan dengan berbagai keterampilan dan pengetahuan yang dimilikinya, sedangkan kemampuan kerja individu menunjukkan potensi seseorang untuk melaksanakan tugas atau pekerjaan. Kemampuan berhubungan erat dengan kemampuan fisik dan mental yang dimiliki setiap orang untuk melaksanakan tugas. 
Menurut Robbins dan Judge (2014), kemampuan (ability) adalah kapasitas individu untuk melaksanakan berbagai tugas dalam pekerjaan tertentu. Seluruh kemampuan seorang individu pada hakekatnya tersusun dari dua perangkat kemampuan yaitu kemampuan intelektual dan kemampuan fisik. Kemampuan intelektual adalah kemampuan yang dibutuhkan untuk melakukan berbagai aktivitas mental, berpikir, menalar dan memecahkan masalah. Tujuh dimensi yang paling sering disebutkan yang membentuk kemampuan intelektual adalah kecerdasan angka, pemahaman verbal, kecepatan persepsi, penalaran induktif, penalaran deduktif, visualisasi spasial, dan ingat. Sedangkan Kemampuan fisik adalah kemampuan melakukan tugastugas yang menuntut stamina, ketrampilan, kekuatan dan karakteristik serupa. Misal, pekerjaan-pekerjaan yang menuntut stamina, ketangkasan fisik, kekuatan kaki atau bakat-bakat serupa yang membutuhkan manajemen untuk mengidentifikasi kemampuan fisik karyawan.

Berdasarkan uraian diatas dapat disimpulkan bahwa yang dimaksud kemampuan karyawan dalam penelitian ini adalah semua potensi yang dimiliki karyawan untuk melaksanakan tugas berdasarkan pengetahuan, sikap, pengalaman, dan pendidikan.

\section{Prestasi Kerja}

Istilah prestasi kerja sering kita dengar atau sangat penting bagi sebuah perusahaan atau organisasi untuk mencapai tujuannya. Dalam konteks pengembangan sumber daya manusia prestasi kerja seorang karyawan dalam sebuah perusahaan sangat dibutuhkan untuk mencapai prestasi kerja bagi karyawan itu sendiri maupun perkelompok demi keberhasilan perusahaan.

Prestasi kerja adalah hasil upaya seseorang yang ditentukan oleh kemampuan karakteristik pribadinya serta persepsi terhadap perannya terhadap pekerjaan Sutrisno (2011:149). Menurut Mangkunegara (2002:33) prestasi kerja adalah hasil kerja secara kualitas dan kuantitas yang dicapai oleh seorang pegawai dalam melaksanakan tugasnya sesuai dengan tanggung jawab yang diberikannya. Prestasi kerja adalah suatu hasil kerja yang dicapai seseorang dengan melaksanakan tugas yang dibebankan kepadanya yang didasarkan atas kecakapan, pengalaman, kesungguhan serta waktu Hasibuan (2008:94).

Untuk mencapai prestasi kerja yang baik, unsur yang paling dominan adalah sumber daya manusia, walaupun perencanaan telah tersusun dengan baik dan rapi tetapi apabila orang atau personil yang melaksanakan tidak berkualitas dan tidak memiliki semangat kerja yang tinggi, maka perencanaan yang telah disusun tersebut akan sia-sia.

Dari beberapa pengertian prestasi kerja yang di kemukakan para ahli di atas dapat dikatakan bahwa prestasi kerja adalah hasil upaya atau kesungguhan seseorang dalam melaksanakan suatu pekerjaan yang dipercayakan kepadanya dengan kecakapan, pengalaman, dan kesungguhannya sesuai dengan tanggung jawab yang telah diberikan kepadanya.

\section{Penelitian Terdahulu}

Wirmayanis (2014) dalam penelitian yang berjudul Pengaruh Kemampuan Kerja, Komitmen Organisasi Dan Motivasi Terhadap Kinerja Pegawai. Kemampuan kerja, komitmen organisasi dan motivasi 
secara bersama-sama berpengaruh positif dan signifikan terhadap kinerja pegawai secara parsial, kemampuan, komitmen organisasi dan motivasi berpengaruh signifikan terhadap kinerja pegawai. Selanjutnya dari hasil statistik, kemampuan kerja mempunyai mempunyai pengaruh yang lebih dominan.

Jayanti (2014) dengan judul Analisis Pengaruh Motivasi Kerja, Kepuasan Kerja, Kontrak Psikologis, Disiplin kerja dan Lingkungan Kerja terhadap Kinerja Karyawan. Hasil penelitian ini menunjukkan bahwa disiplin kerja memiliki pengaruh yang signifikan terhadap kinerja karyawan dan kepuasan kerja memiliki pengaruh positif dan signifikan terhadap kinerja karyawan. Persamaan peneliti ini dengan peneliti yang dilakukan penulis adalah samasama meneliti pengaruh disiplin kerja. Perbedaannya terletak pada penambahan variabel yang dilakukan penulis yaitu kemampuan kerja terhadap prestasi kerja karyawan, peneliti meneliti di PT. Pelabuhan Indonesia IV Makassar (Persero).

Aan Soelehan dan Suwandi Sukartaat maja (2009) dengan judul Pengaruh Disiplin Kerja, Lingkungan Kerja dan Semangat Kerja terhadap Prestasi Kerja. Disiplin kerja, lingkungan kerja dan semangat kerja berpengaruh signifikan terhadap prestasi kerja.

\section{Gambar 1. Kerangka Konseptual}

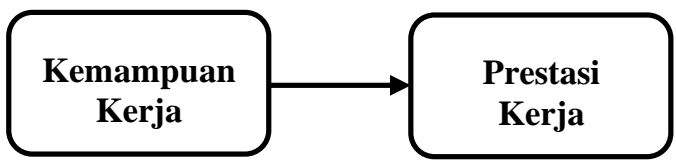

\section{METODE PENELITIAN}

Penelitian ini bersifat asosiatif yang bertujuan untuk mengetahui hubungan antara dua variabel atau lebih yang berfungsi untuk menjelaskan, meramalkan, dan mengontrol fenomena (Sugiyono, 2013) (dalam Kumara dan Utama, 2016:8). Metode penelitian menggunakan pendekatan kuantitatif yang menghasilkan data dalam bentuk angka yang akan disusun berdasarkan pendekatan kuantitatif bersifat asosiatif kaukalistik karena peneliti ingin melihat pengaruh hubungan atau pengaruh sebab akibat antar variabel kemampuan kerja (X) sebagai variabel independent, dan variabel prestasi kerja karyawan (Y) sebagai variabel dependent

Teknik Pengumpulan Data, Observasi yaitu suatu metode pengumpulan data dengan pengamatan langsung di lokasi yang dijadikan obyek penelitian. Kuesioner adalah metode pengumpulan data yang dilakukan dengan mengajukan lembaran angket yang berisi daftar pertanyaan kepada responden. Teknik angket adalah pengumpulan data dengan menyebar pertanyaan kepada responden dan responden akan memberikan respon atas pertanyaan tersebut.

Adapun populasi yang dimaksud dalam penelitian ini adalah seluruh karyawan pada kantor Pusat PT. Pelabuhan Indonesia IV Makassar yang berjumlah 300 orang. Pengambilan sampel dalam penelitian ini dengan teknik probability sampling yaitu proportionate stratified random sampling dengan menggunakan rumus sloving. Berdasarkan rumus tersebut dapat dihitung sampel dari populasi berjumlah 300 orang dengan tingkat kesalahan $10 \%$, maka sampel 75 responden.

Analisis data adalah proses mencari dan menyusun secara sistematis data yang diperoleh dari hasil wawancara, catatan, lapangan dan bahan-bahan lainnya, sehingga mudah dipahami dan temuanya dapat diinformasikan kepada orang lain. 
(Bogdan dalam sugiyono, 2013:24).

Berdasarkan tujuan yang ingin di capai dalam penelitian ini maka data yang diperoleh akan di olah dan di paparkan berdasarkan statistic deskriptif. untuk kepentingan analisis dan pengujian hipotesis digunakan analisis regresi linear berganda yang diolah menggunakan program SPSS.

Uji Hipotesis. Dalam uji simultan atau uji $\mathrm{F}$ digunakan untuk mengetahui pengaruh variabel independent secara bersama-sama (simultan) terhadap variabel dependent dilakukan dengan menggunakan uji fiest yaitu dengan cara membandingkan antara $\mathrm{F}$ table, dengan rumus secara matematis sebagai berikut : Apabila nilai signifikan F hitung < nilai signifikan $a=0,05$ maka hipotesis yang diajukan diterima. Sebaiknya jika nilai signifikan $F$ hitung $>$ nilai signifikan a $=0,05$ maka hipotesis yang diajukan tidak dapat diterima (Sugiyono 2006 : 11). Uji t dilakukan untuk menguji kemaknaan koefisien parsial.apabila $\mathrm{t}$ hitung $\geq \mathrm{t}$ tabel maka $\mathrm{H}_{\mathrm{O}}$ ditolak. Dengan demikian variabel independen dapat menerangkan variabel dependen. Sebaliknya apabila t hitung $\leq$ $\mathrm{t}$ tabel maka $\mathrm{H}_{\mathrm{O}}$ diterima sehingga dapat dikatakan variabel independen (disiplin dan kemampuan) tidak dapat menjelaskan variabel dependen (prestasi kerja) dengan kata lain tidak ada pengaruh dari variabel yang diuji.(Sugiyono 2006: 124). Uji koefisien determinasi $\left(\mathrm{R}^{2}\right)$ digunakan untuk mengetahui kontribusi variabel bebas dalam menjelaskan variabel terikat. Semakin besar nilai koefisien determinasi, maka menunjukkan semakin besar pula pengaruh variabel independen terhadap variabel dependen.

\section{HASIL DAN PEMBAHASAN}

Hasil analisis regresi berganda dengan menggunakan uji parsial didapatkan bahwa ada pengaruh positif dan signifikan antara kemampuan kerja dengan prestasi kerja, ini ditandakan dengan nilai thitung yang lebih besar dari t tabel yaitu 2,149>1,66629 dan nilai peluang (sig) pengujian sebesar 0,035 yang lebih kecil dari 0,05. Hasil tersebut menunjukkan bahwa disiplin kerja berpengaruh positif dan signifikan terhadap prestasi kerja pada PT. Pelabuhan Indonesia IV Makassar (Persero).

Kemampuan kerja berhubungan dengan prestasi seorang karyawan dalam menyelesaikan pekerjaannya. Karyawan yang memiliki kemampuan yang baik akan mampu menyelesaikan pekerjaan yang dimilikinya dengan baik, sehingga karyawan akan memiliki prestasi kerja yang baik. Karena karyawan yang memiliki kemampuan kerja yang baik akan cepat tanggap dalam menyelesaikan pekerjaan yang diberikan kepadanya. Karyawan yang dapat menyelesaikan pekerjaannya dengan baik akan memiliki tingkat prestasi kerja yang baik. Seperti halnya pada PT. PELINDO, karyawan yang mampu menyelesaikan pekerjaannya dengan baik, pasti memiliki kemampuan yang baik, sehingga memiliki tingkat prestasi kerja yang baik.

Penelitian ini sejalan dengan penelitian yang dilakukan oleh Wirmayanis (2014) dalam penelitian yang berjudul Pengaruh Kemampuan Kerja, Komitmen Organisasi Dan Motivasi Terhadap Kinerja Pegawai. Kemampuan kerja, komitmen organisasi dan motivasi secara bersama-sama berpengaruh positif dan signifikan terhadap kinerja pegawai secara parsial, kemampuan, komitmen organisasi dan motivasi berpengaruh signifikan terhadap kinerja pegawai. Selanjutnya dari hasil statistik, kemampuan kerja mempunyai mempunyai pengaruh yang lebih dominan. Hipotesis diterima. 


\section{E. KESIMPULAN}

Terdapat pengaruh antara variabel kemampuan kerja terhadap prestasi kerja pada PT. Pelabuhan Indonesia IV Makassar (Persero). Hal ini dibuktikan dengan nilai t hitung yang lebih besar dari nilai $t$ tabel $(2,149>1,66629)$ dan nilai $P$ yang lebih kecil dari $\alpha(0,035<0,05)$.

\section{DAFTAR PUSTAKA}

Aan Soelehan dan Suwandi Sukartaat Maja (2009), Pengaruh Disiplin Kerja, Lingkungan Kerja dan Semangat Kerja terhadap Prestasi Kerja Warga SMP Printis Kecamatan Pancoran Mas Kota Depok.

A.A. Anwar Prabu Mangkunegara, (2002). Manajemen Sumber Daya Manusia. Bandung : PT. Remaja Rosda Karya.

(2013). Manajemen Sumber Daya Manusia. Bandung : PT. Remaja Rosda Karya.

Ahmad Jais (2017), Pengaruh Disiplin Kerja Dan Lingkungan Kerja Terhadap Prestasi Kerja Pegawai Pada Rumah Sakit Umum Daerah H. Andi Sulthan Daeng Radja Kabupaten Bulukumba, Makassar, Fakultas Ekonomi Dan Bisnis Islam UIN ALAUDDIN Makassar.

Ahmad Nur Rofi (2012), Pengaruh Disiplin Kerja dan Pengalaman Kerja Terhadap Prestasi Kerja Karyawan Pada Departemen Produksi PT. Leo Agung Raya Semarang. Jurnal Ilmu Manajemen dan Akuntansi Terapan 3, (1), 2-10.
Ari Darmawan, Muhammad Ferryal

Ramadhan (2018), Pengaruh

Kemampuan Kerja, Motivasi,

Disiplin Kerja Dan Pengembangan

Karir Dalam Meningkatkan Kinerja

Karyawan PT. Taman Rekreasi

Sengkaling, Fakultas Ilmu

Administrasi Universitas

Brawijaya.

Azar Sariah (2017), Pengaruh Disiplin Kerja Terhadap Prestasi Kerja Karyawan Pabrik Kelapa Sawit PT. Multimas Nabati Asahan, Medang, Fakultas Ekonomi Dan Bisnis Islam Universitas Islam Negeri Sumetera Utara.

Davis, Keith, (2011). Perilaku Dalam Organisasi, Jakarta : Erlangga.

Edy, Sutrisno, (2011). Manajemen Sumber Daya Manusia, Jakarta : Kencana.

Farlen, Frans (2011), Pengaruh Motivasi Kerja dan Kemampuan Kerja terhadap Kinerja Karyawan (Studi pada Karyawan PT. United Tractors Tbk Samarinda). Skripsi. Yogyakarta : Universitas Pembangunan Nasional Veteran.

Franco Bryan Logor, Petrus Tumade, Rudy S. Wenas (2015), Pengaruh Disiplin Kerja,Pelatihan,Dan Kemampuan Kerja Terhadap Prestasi Kerja Karyawan Pada PT. Hasjrat Abadi Manado. Jurnal EMBA 3, (3), 1151-1161.

Gibson dkk, (2011), Proses-proses Struktur Perilaku Organisasi, Jakarta : Erlangga.

Hasibuan, Malayu. (2008), Manajemen Sumber Daya Manusia, cetakan ke11, Jakarta : PT. Bumi Aksara 
, (2010), Manajemen Sumber

Daya Manusia, Jakarta : PT.

Bumi Aksara.

(2012), Manajemen Sumber

Daya Manusia, Jakarta : Bumi

Aksara.

(2017), Manajemen Sumber

Daya Manusia, Edisi Revisi,

Jakarta : Bumi Aksara.

Jayanti (2014), Analisis Pengaruh Motivasi Kerja, Kepuasan Kerja, Kontrak Psikologis, Disiplin Kerja dan Lingkungan Kerja terhadap Kinerja Karyawan RSUD Kota Semarang.

Mangkunegara, (2015), Manajemen Sumber Daya Manusia Perusahaan, Bandung : PT. Remaja Rosda Karya.

Moch Riza Afgani (2017), Pengaruh Kemampuan, Motivasi Kerja Dan Disiplin Terhadap Produktivitas Kerja Karyawan Di PT. Slamet Langgeng Kabupaten Purbalingga, Jawa Tengah, Program Studi Manajemen Fakultas Ekonomi Dan Bisnis Universitas Muhammadiyah Purwokerto.

Moenir, (2008), Manajemen Pelayanan Umum di Indonesia, Jakarta : PT. Bumi Aksara.

Mu'ah, Masram, (2017), Manajemen Sumber Daya Manusia Profesional, Cetakan Pertama, Sidoarjo : Zifatama Publisher.

Muhammad Dicky Afifi (2015), Pengaruh Kemampuan Kerja Dan Motivasi Kerja Terhadap Prestasi Kerja (Studi Pada Karyawan PR.
Sejahtera Abadi Malang). Jurnal Administrasi Bisnis 29, (1).

Nasution, S, (2011), Metode Research ( Penelitian Ilmiah), Jakarta : Bumi Aksara.

Nining Syafitriningsih (2017), Pengaruh Disiplin Kerja Dan Motivasi Kerja Terhadap Kinerja Karyawan Di PT. Inkabiz Indonesia, Jakarta, Fakultas Ekonomi Dan Bisnis Universitas Islam Negeri Syarif Hidayatullah.

Nurhayati (2017), Pengaruh Kemampuan Kerja, Komitmen Organisasi, dan Disiplin Kerja Terhadap Kinerja Pegawai Bagian Umum Sekretariat Daerah Kabupaten Soppeng, Makassar, Program Pascasarjana STIE AMKOP Makassar.

Prijodarminto, Soegeng, (1994), Disiplin Kiat Menuju Sukses, Jakarta : Pradaya Paramita.

Rivai dan ella Sagala, (2013), Manajemen Sumber Daya Manusia untuk Perusahaan, Jakarta : Rajawali Pers.

Rivai, Veithzal, (2011), Manajemen Sumber Daya Manusia Untuk Perusahaan dari Teori dan Praktik, Jakarta : PT. Raja Grafindo Persada.

, (2012), Manajemen Sumber Daya Manusia Untuk Perusahaan dari Teori dan Praktik, Jakarta : PT. Raja Grafindo Persada.

Robbins S SP, dan judge, (2014), Perilaku Organisasi,Buku 2, Jakarta : Salemba.

ST. Maryam (2018), Pengaruh Motivasi Dan Komitmen Karyawan Terhadap Prestasi Kerja Karyawan 
Pada PT. PLN (Persero) Wilayah SulSelBar, Makassar, Sekolah Tinggi Ilmu Ekonomi Amkop Makassar.

Sugiyono, (2013), Metode Penelitian Kuantitatif, Kualitatif dan R \& D, Bandung : Alfabeta.

, (2012), Metode Penelitian Bisnis, Bandung : Alfabeta.

,(2010), Statistika untuk Penelitian, Bandung : Alfabeta.

Sunyoto, D, (2012), Manajemen Sumber Daya Manusia, Yogyakarta : CAPS.

Tety Asmiarsih (2013), Pengaruh Pengawasan Terhadap Disiplin Kerja Pegawai Badan Kepegawaian Daerah Kabupaten Brebes, Semarang, Fakultas Ilmu Sosial.

Thoha, Miftah, (2011), Perilaku Organisasi, Konsep Dasar dan Aplikasinya, Jakarta : Rajawali Pers.

Wirmayanis, Suziana (2014), Pengaruh Kemampuan Kerja, Komitmen Organisasi dan Motivasi Terhadap Kinerja Pegawai. Jurnal Dinamika Manajemen 2, (3), 29-221. 